\title{
The hormonal control of fat metabolism in animals
}

\section{By T. E. C. WeEkes, Department of Agricultural Biochemistry and Nutrition, University of Newcastle upon Tyne, Newcastle upon Tyne $N E_{1}{ }_{7} R U$}

Of the three main components of the adult animal, bone, skeletal muscle and fat, the fat depots have the most variable growth rate. Growth of adipose tissue depends on the coordinated increase in cell size (hypertrophy) and cell number (hyperplasia) in the fat tissues. The endocrine system will affect the balance between anabolic and catabolic processes within the adipocyte and will influence the partitioning of energy surplus to maintenance requirements between muscle and adipose tissue deposition and heat production. Much research effort has, therefore, been directed towards understanding the endocrine control systems to enable the partitioning of nutrients to be manipulated for more efficient meat production. Manipulation may be by selection of superior stock, by control of the type and amount of diet or by treatment with anabolic agents.

\section{Brown adipose tissue in farm animals}

If we were considering the biochemical processes of fat metabolism in the rat, an important site of endocrine regulation would be the brown adipose tissue, involved in non-shivering thermogenesis and 'diet-induced thermogenesis'. In contrast, brown adipose tissue does not develop in adult sheep during cold acclimation (Cox et al. 1978). The thermogenic response to noradrenaline is also relatively small in ruminants. Non-shivering thermogenesis takes place in skeletal muscle rather than brown adipose tissue. Brown adipose tissue was detected in 2-3 month-old pigs, but not in older animals (Dauncey et al. 1981). The consequences of the apparent lack of brown adipose tissue in adult farm animals are worthy of consideration, but for the present interest has been focused on the endocrine regulation of the processes of lipolysis, lipogenesis and net lipid deposition in white adipose tissue. In pigs and ruminant species the adipose tissue itself is the major site of de novo lipogenesis in nonlactating animals.

\section{Adipose tissue cellularity}

Growth of adipose tissue depends on the number and size of adipocytes present. Adiposity is more clearly associated with increased adipose cell size than with cell number (Wood et al. 1978). Studies using the obese Ossabaw pig suggest that once adipocytes reach a certain mean or maximum size, a new population of cells is recruited, allowing further increases in fat deposition (Etherton, 1980). Cell size also influences the metabolic capacity of the tissue to synthesize fatty acids and esterify exogenous fatty acids (Etherton \& Allen, 1980), larger adipocytes being more active than smaller ones, although very large adipocytes have a reduced 
metabolic capacity, coupled with an insensitivity to insulin. This topic has been reviewed in detail recently by Hood (1982).

\section{Endocrine regulation of fat metabolism in pigs}

The ability of a hormone to influence tissue metabolism depends on circulating levels of the hormone, the rate of delivery of the hormone to the target tissues, the number and affinity of hormone receptors present and the responsiveness of post-receptor events to hormone action. Most studies with farm animals have concentrated on the first of these factors, which is the most likely to offer immediate practical applications, for example in breeding programmes.

Large differences in body composition exist between breeds of pig, providing an attractive model of the endocrine regulation of fat metabolism. When compared with the Yorkshire breed, the obese, slow growing Ossabaw has a greater lipogenic capacity, lower growth hormone (GH) secretion, fewer muscle nuclei, mild insulin insensitivity and a greater insulin response to arginine injection (Wangsness et al. 1977). The relatively lean, stress sensitive Pietrain on the other hand, when compared with the Large White, has a greater rate of fat mobilization during fasting, with a greater sensitivity to the $\beta$-adrenergic actions of catecholamines infused during anaesthesia and a lower threshold of sensitivity to sympathetic stimulation. Plasma insulin responses to a number of stimuli are lower in the Pietrain breed, but tissue sensitivity to insulin was also lower (Gregory et al. 1977; Wood et al. 1977). This pattern contrasts with the inverse relationship between insulin secretion and tissue sensitivity to insulin which occurs in other forms of obesity (Wangsness et al. 1977; Olefsky, 1981).

Studies at Newcastle have investigated the consequences of selection within a single breed, the Large White, which is not halothane sensitive (Webb, 1980). Two lines of pigs were developed by W. C. Smith and M. Ellis (University of Newcastle) and R. Laird (West of Scotland College of Agriculture). A 'control' line was randomly bred within the line, while a 'selection' line was bred over eleven generations from common ancestry. Selection was by performance testing, on an ad lib. feeding regimen, using an index comprising backfat thickness, growth rate and group feed conversion efficiency. In comparison to the control line, the selection line averaged a $23 \%$ reduction in backfat thickness, a $10 \%$ improvement in feed conversion efficiency and a $5 \%$ improvement in lean tissue growth rate, with no change in overall growth rate and a small reduction in voluntary feed intake. The latter was only responsible for a small proportion of the differences in growth and carcass composition between lines (Whittemore et al. 1982). Studies conducted by R. I. Richardson, D. A. Raeside and myself were designed to characterize changes in insulin secretion, lipolysis and lipogenic enzyme activities that had accompanied selection and to determine whether such measurements could be used in future selection programmes, as an alternative to the performance test.

Preliminary studies using small numbers of boars of $35 \mathrm{~kg}$ body-weight established that plasma insulin responses to intravenous injections of glucose or 
noradrenaline tended to be greater in the control line, while the latter injection induced a slightly greater rise in plasma non-esterified fatty acid (NEFA) concentrations in selection line boars. Two further experiments were conducted using boards fed ad lib. from weaning to slaughter at approximately $90 \mathrm{~kg}$ body-weight. On reachng slaughter weight, animals were fasted overnight and subjected to an intravenous injection of noradrenaline $(25 \mu \mathrm{g} / \mathrm{kg}$ body-weight). The plasma insulin and NEFA response areas above basal were measured. In both experiments clear differences in animal performance existed between the lines, but there were no significant differences in insulin or NEFA response areas. Similar results were obtained in a third experiment comparing the Newcastle control line with boars obtained from five commercial breeders participating in the Meat and Livestock Commission's Pig Improvement Scheme. Thus it could be argued that all three lines represented a single population of Large White boars. When data from all lines were combined, the insulin response to noradrenaline was significantly correlated with carcass fat measurements, but the degree of association was relatively weak ( $r$ values in the range $0.23-0.30, n 82$ ). Not unexpectedly basal insulin levels were not significantly correlated with carcass fat measurements. Other workers have also observed that basal hormone levels were very poor predictors of offspring's milk production in dairy bulls (Osmund et al. 1981). We must conclude that within a single breed the relationship between insulin secretory responses and carcass fat deposition is not sufficiently strong to be of use for selection purposes.

Combined measurements of insulin and $\mathrm{GH}$ secretion might provide a better predictor of carcass composition than either hormone alone, in view of the lipolytic and protein anabolic actions of GH in pigs (Anderson et al. 1981). Selection of other lines of pigs for high backfat thickness has led to a reduction in GH levels (Lund-Larsen \& Bakke, I975; Althen \& Gerrits, I 976). It should be noted that no significant relationships existed in our studies between plasma NEFA responses to noradrenaline injection and carcass fat measurements. In animals selected and reared under an ad lib. feeding regimen starvation-induced net lipolysis is unlikely to occur, so that differences in rates of fat mobilization will not determine differences in body fat deposition (Gregory et al. 1980). Direct measurements of rates of lipogenesis and unstimulated lipolysis in biopsy samples taken from obese and lean lines of pigs fed ad lib. support this hypothesis (Scott et al. 198I).

\section{Lipogenic enzyme activities in adipose tissue}

While subtle differences in the endocrine environment, perhaps at the receptor or post-receptor levels, may ultimately determine the capacity of an individual animal to deposit fat, a better prediction of fatness, of use in a breeding programme, may be achieved by measurement of the activities of enzymes participating directly in the lipogenic process. The specific activities of ATP-citrate lyase, malate dehydrogenase $\left(\mathrm{NADP}^{+}\right)$, glucose 6-phosphate dehydrogenase and 6-phosphogluconate dehydrogenase in subcutaneous adipose 
tissue are significantly higher in the obese than in the lean line of Duroc pigs, regardless of age or feeding regimen (Steele \& Frobish, 1976). We have measured the activities of the above enzymes and of acetyl-CoA carboxylase and isocitrate dehydrogenase $\left(\mathrm{NADP}^{+}\right)$in perirenal and subcutaneous adipose tissues taken at slaughter from pigs of the Newcastle lines grown under a variety of feeding regimens (Raeside $e t$ al. 1980, I982). Feeding level and line influenced the specific activities of the enzymes measured, the former having the greater effect. The combined specific activities of the four NADP-linked enzymes in the inner layer of backfat was relatively strongly correlated with carcass fat measurements, both within a line and for the two lines combined ( $r$ values up to $0.7-0.8, n 53$ per line). The sum of the activities of the same NADP-linked dehydrogenases has been used as a selection index in a study using German Landrace pigs (Rogdakis, 1979). A highly significant differentiation in both enzyme levels and backfat thickness was obtained after only three generations when animals were selected solely on the basis of high or low enzyme activity.

\section{Receptor and post-receptor events}

The process of lipolysis appears to be broadly similar in farm animals and rats, with the key enzyme being hormone-sensitive lipase. Lipolysis is sensitive to the same array of stimuli- the sympathetic nervous system, catecholamines, GH and glucagon, with insulin generally accepted as an antilipolytic hormone. Glucagon is lipolytic in ruminants (Bolton et al. 1983), but the responses of ruminant (Brockman, I978) and porcine (Ingram \& Kaciuba-Uscilko, I 980) adipose tissue to glucagon are relatively poor. In dairy cows the increased rate of lipid mobilization in early lactation is associated with increased numbers of $\beta$-adrenergic receptors per adipocyte (Jaster \& Wegner, I98I). The lipolytic actions of GH, and possibly of prolactin, as homoeorhetic signals controlling the partitioning of nutrients in farm animals have been emphasized by Bauman et al. (1 982 ). GH also opposes the lipogenic action of insulin on ovine adipose tissue maintained in culture (Vernon, I982).

Recent research has considerably increased our understanding of the actions of insulin on the adipocyte. The total number of insulin receptors present on the plasma membrane depends on the relative rates of receptor synthesis and degradation. An intracellular pool of receptors may exist, receptors recycling back to the plasma membrane (Lane, 1981). An inverse relationship between ambient insulin concentrations and the cell surface insulin receptor level has been described in several tissues and cell types, including ruminant hepatocytes (Gill \& Hart, 1981), described as insulin-induced 'down-regulation' of plasma membrane insulin receptors. Lane ( $198 \mathrm{I}$ ) suggests that down regulation occurs by insulin-induced internalization of the receptors, without altering the rates of receptor synthesis or degadation. A somewhat analogous mechanism has been proposed to explain the action of insulin in stimulating glucose transport across the plasma membrane, by stimulating the translocation of glucose transport units from an intracellular pool 
to the plasma membrane (Karnieli et al. r98I). Tentative proposals have been advanced by Denton et al. (1981) to explain the mechanism of insulin action on enzyme activities within the adipocyte. Insulin binding to its receptor may increase the activity of a protein kinase, distinct from the better known cyclic AMPdependent protein kinase. The insulin-stimulated kinase may phosphorylate a number of proteins, including acetyl-CoA carboxylase, resulting in increased rates of de novo lipogenesis and protein synthesis and a decreased rate of lipolysis.

The above hypotheses are still very tentative and their applicability to farm animals is unknown. The limited studies which have been performed suggest that the properties of insulin receptors in adipose tissue of the pig (Etherton \& Walker, 1982) and the sheep (Vernon et al. I98I) and in ruminant hepatocytes (Gill \& Hart, I98I) are not greatly different from those of analogous receptors in the rat and man. Compared with rats, adipocytes from ruminants and pigs appear to be less responsive to insulin in vitro in terms of the maximal response to the hormone, although the concentration of insulin producing a half maximal effect is in the physiological range of $50-100 \mu \mathrm{U} / \mathrm{ml}$ (Vernon, 1980 ). Differences in responses between farm animals and rats may partly reflect technical difficulties in working with the relatively fragile adipocytes of domestic livestock, so that many studies have been carried out using tissue slices rather than isolated adipocytes. It can be argued that the unusual species is the rat, particularly the young animal, whose adipocytes are especially responsive to insulin (Etherton, 1982).

In the case of ruminants a lower response to insulin may be related to the different biochemical pathway of lipogenesis in these species. Although glucose and L-lactate can serve as carbon sources for de novo lipogenesis, acetate is the major carbon source, glucose serving as a source of glycerol 3-phosphate and of reduced NADPH via the pentose phosphate pathway. The limited use of glucose as a carbon source was previously ascribed to the low activities of ATP-citrate lyase and malate dehydrogenase ( $\mathrm{NADP}^{+}$) in ruminant adipose tissue (Bauman, 1976), but doubt has been cast on the rate-limiting role of these enzymes by the ability of L-lactate to serve as a carbon precursor (Prior \& Jacobson, 1979). While L-lactate may not represent a major carbon source in adult ruminants (Robertson et al. 198I), the preferential use of L-lactate compared with glucose may mean that the ATP-citrate lyase and malate dehydrogenase $\left(\mathrm{NADP}^{+}\right)$pathway is operative in ruminant adipose tissue, perhaps even being involved in lipogenesis from acetate as well as from L-lactate as a carbon source (Prior et al. 198r). Glucose use may be limited by a restricted flux through the phosphofructokinase reaction (Yang et al. 1982).

A recent review argued provocatively that glucose is a more powerful stimulus than insulin for lipogenesis in ruminants (Prior \& Smith, r 982 ), the major effect of insulin being to increase adipocyte glucose uptake and lipoprotein lipase activity, the latter stimulating plasma triglyceride hydrolysis and uptake of preformed fatty acids by the adipocyte. Somewhat surprisingly, Prior \& Smith (1982) reported that insulin was not required for stimulation of acetyl-CoA carboxylase activity on refeeding starved steers. When acetate serves as a carbon source, insulin-induced 


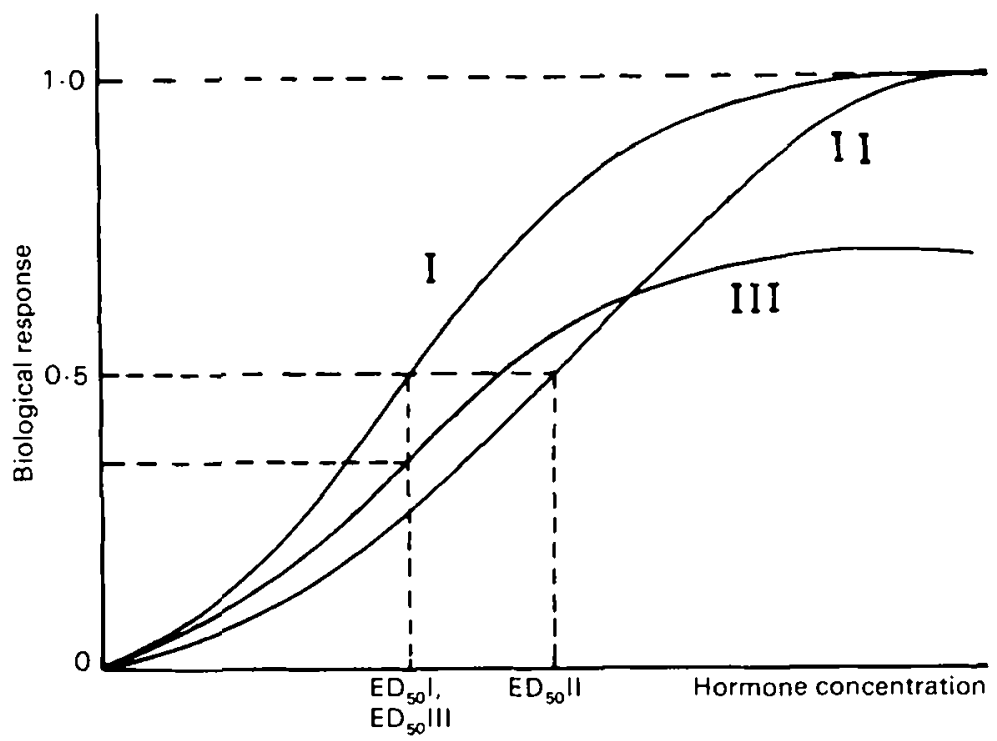

Fig. 1. Representation of possible relationships between a hormone-stimulated pathway of metabolism and hormone concentration. I, Normal; II, change in hormone sensitivity, with normal maximal response but altered hormone concentration producing a half-maximal effect $\left(E D_{50} I I\right)$; III, change in hormone responsiveness, with an altered maximal response, but no change in hormone concentration required for a half-maximal effect $\left(\mathrm{ED}_{50} \mathrm{III}\right)$. Adapted from Kahn (I 980$)$.

increases in pyruvate kinase and pyruvate dehydrogenase activities (Denton $e t$ al. 198I) would not affect the rate of de novo lipogenesis.

The responsiveness of adult ruminant adipocytes to insulin may be modified by reproductive status (Vernon et al. 1981) or by nutrition. Rates of lipogenesis are increased when ruminants are fed on cereal-based diets (Piperova \& Pearce, 1982) or when animals are refed after a period of dietary restriction. It is not known whether such changes are related to changes in the response of the adipocytes to insulin. Information about the mechanisms responsible for changes in hormone effectiveness in such situations can be provided from the shape of the hormone-biological function dose-response curve (Fig. I). In a system with spare hormone receptors, moderate changes in the number or affinity of the receptors would cause a shift in the hormone dose-response curve, without altering the maximal response to the hormone. Such changes have been defined as changes in sensitivity (Kahn, 1980). Changes in post-receptor steps in the pathway of hormone action will in certain circumstances result in an altered maximal effect of the hormone, with an unchanged hormone concentration required to produce a half-maximal response $\left(E D_{50}\right)$. This type of shift has been described as a change in hormone responsiveness (Kahn, 1980). Combined changes in sensitivity and responsiveness may also occur.

This approach has recently been applied in conjunction with the euglycaemic insulin clamp procedure to study changes in insulin action in vivo in adult sheep subjected to chronic cold exposure (Weekes et al. 1982). Previous work established that insulin secretory responses to a number of stimuli are reduced by 
chronic cold exposure (Sasaki et al. 1982). Our studies demonstrated that cold exposure increased tissue responsiveness to insulin, without changing sensitivity to the hormone. The application of similar techniques for other hormones in growing animals may provide a clearer insight into the hormonal interactions which regulate net lipid deposition in farm livestock.

Financial support from the Agricultural Research Council, Meat and Livestock Commission and Japan Society for the Promotion of Science is gratefully acknowledged.

\section{REFERENCES}

Althen, T. G. \& Gerrits, R. J. (1976). F. Anim. Sci. 42, 1490.

Anderson, L. L., Bohnker, C. R., Parker, R. O. \& Kertiles, L. P. (1981). J. Anim. Sci. 53, 363.

Bauman, D. E. (1 976). Fedn Proc. Fedn Am. Socs exp. Biol. 35, 2308.

Bauman, D. E., Eisemann, J. H. \& Currie, W. B. (I982). Fedn Proc. Fedn Am. Socs exp. Biol. 41, 2538 .

Bolton, S. C., Weekes, T. E. C., Godden, P. M. M. \& Armstrong, D. G. (1983). Proc. Nutr. Soc. $42,48 \mathrm{~A}$.

Brockman, R. P. (1978). Can. vet. $\mathcal{F} .19,55$.

Cox, R. W., Leat, W. M. F., Chauca, D., Peacock, M. A. \& Bligh, J. (1978). Res. vet. Sci. $25,5^{8}$.

Dauncey, M. J., Wooding, F. B. P. \& Ingram, D. L. (1981). Res. vet. Sci. 31,76 .

Denton, R. M., Brownsey, R. W. \& Belsham, G. J. (I981). Diabetologia 21, 347.

Etherton, T. D. (1980). Growth 44, 182.

Etherton, T. D. (1982). J. Anim. Sci. 54, 58.

Etherton, T. D. \& Allen, C. E. (1980). Y. Anim. Sci. 50, 1073.

Etherton, T. D. \& Walker, O. A. (1982). Endocrinology $110,1720$.

Gill, R. D. \& Hart, I. C. (1981). Horm. Metab. Res. 13,603.

Gregory, N. G., Lovell, R. D., Wood, J. D. \& Lister, D. (1977). F. agric. Sci., Camb. 89, 407.

Gregory, N. G., Wood, J. D., Enser, M., Smith, W. C. \& Ellis, M. (1980). F. Sci. Food Agric. 31, 567 .

Hood, R. L. (1982). Fedn Proc. Fedn Am. Socs exp. Biol. 41, 2555.

Ingram, D. L. \& Kaciuba-Uscilko, H. (1980). Horm. Metab. Res. 1 2, 421.

Jaster, E. H. \& Wegner, T. N. (1981). F. Dairy Sci. 64, 1655 .

Kahn, C. R. (1980). Metabolism 27, 455.

Karnieli, E., Zarnowski, M. J., Hissin, P. J., Simpson, I. A., Salans, L. B. \& Cushman, S. W. (1981). F. biol. Chem. 256,4772 .

Lane, M. D. (1981). Nutr. Rev. 39, 417 .

Lund-Larsen, T. R. \& Bakke, H. (1975). Acta agric. Scand. 25, 23 I.

Olefsky, J. M. ( $198 \mathrm{I})$. Diabetes 30,148 .

Osmund, T. J., Carr, W. R., Hinks, C. J. M., Land, R. B. \& Hill, W. G. (1981). Anim. Prod. 32, 159.

Piperova, L. S. \& Pearce, J. (1982). Int. F. Biochem. 14, $35^{1}$.

Prior, R. L. \& Jacobson, J. J. (1979). J. Anim. Sci. 49, 1410.

Prior, R. L. \& Smith, S. B. (1982). Fedn Proc. Fedn Am. Socs exp. Biol. $41,2545$.

Prior, R. L., Smith, S. B. \& Jacobson, J. J. (1981). Arch. Biochem. Biophys. $211,202$.

Raeside, D. A., Weekes, T. E. C., Ellis, M. \& Laird, R. (1982). Anim. Prod. 34, 366.

Raesidc, D. A., Weekes, T. E. C., Ellis, M. \& Smith, W. C. (1980). Anim. Prod. 30, 462.

Robertson, J. P., Faulkner, A. \& Vernon, R. G. (1981). Biochim. biophys. Acta 665, 511.

Rogdakis, E. (1979). 3oth Ann. Meeting E.A.A.P., Harrogate. Paper 5.1 3.

Sasaki, Y., Takahashi, H., Aso, H., Ohneda, A. \& Weekes, T. E. C. (1982). Endocrinology III, 2070.

Scout, R. A., Cornelius, S. G. \& Mersmann, H. J. (1981). J. Anim. Sci. 52, 505. 
Steele, W. C. \& Frobish, L. T. (1 976$)$. Growth 40,369 .

Vernon, R. G. (1980). Prog. Lipid Res. 19, 23.

Vernon, R. G. (1982). Int. Y. Biochem. 14, 255.

Vernon, R. G., Clegg, R. A. \& Flint, D. J. (198I). Biochem. F. 200, 307.

Wangsness, P. J., Martin, R. J. \& Gahagan, J. H. (1977). Am. f. Physiol. 233, Ero4.

Webb, A. J. (1980). Anim. Prod. 31, 101.

Weekes, T. E. C., Sasaki, Y. \& Tsuda, T. (1983). Am. F. Physiol. (In the Press.)

Whittemore, C. T., Henderson, R., Ellis, M., Smith, W. C., Laird, R. \& Wood, J. D. (1982). Anim. Prod. 34, 380.

Wood, J. D., Enser, M. B. \& Restall, D. J. (1978). Anim. Prod. 27, I I.

Wood, J. D., Gregory, N. G., Hall, G. M. \& Lister, D. (1977). Br. F. Nutr. 37, 167.

Yang, Y. T., White, L. S. \& Muir, L. A. (1982). J. Anim. Sci. 55, $3^{1} 3$. 